\title{
Work Environment and its Impact on Triple Constraint of Project Management
}

\author{
*Syed Ali Raza Hamid1, Hateem Adnan Ghafoor1, Tamkeen Zehra Shah² \\ ${ }^{1}$ Institute of Engineering and Management Sciences, Foundation University, Pakistan \\ ${ }^{2}$ Roots School System, Pakistan \\ *alirazahamid@hotmail.com
}

\begin{abstract}
Project management's fundamental concern is to effectively manage its triple constraints throughout the life cycle of a project to maximize productivity. At the same timework environment is considered a key feature, which influences the framework of project management. The present study assesses the impact of the work environment on the triple constraints (Scope, Time and Cost) of projects in the IT industry. The theoretical framework comprises Remuneration, Job Satisfaction, Job Security, and Working Hours as components of work environment and triple constraints as the dependent variable. Three hundred Project Managers across a number of IT firms have been approached, out of which 279 have responded to the questionnaire. The measurement tool has been developed by the researcher except for one construct, which has been adopted, followed by a pilot study. Inferential statistics have been applied to test the data. The study concludes that all project managers view a flexible and conducive work environment as bearing a strong relationship with the triple constraint of project management.
\end{abstract}

Key words: Project Management, Work Environment, Triple Constraints, Job satisfaction, Pakistan

\section{Introduction}

Project management has gained an increased importance ever since the advent of information technology in the business world. Where key business solutions had to be delivered through IT, it became imperative that conventional processes had to be phased out and automation had to be phased in on a project basis. Even companies starting from scratch on a digital platform found the project management model easy to adopt, as information processes and technology, by their very nature, called for skilled experts to work as teams on their specific area. The information age has made the business cycle not only fast, but also global, bringing businesses in disparate geographical regions closer, allowing them to compete for timely delivery of various projects, related to IT and otherwise. Global juxtaposition and competition called for corporations to set meaningful and standard criteria of their projects' success (Cooke-Davies, 2002), emphasizing the need for developing skills for an effective project management. This need mobilized professional institutions to conduct corporate training in project management for industries to work towards sound project completion (Hartenian et al. 2001). According to the Project Management Institute (PMI), project managers should continue assessing their productivity and efficiency issues related to the work environment where projects operate, and in the same fashion, organizations should pay attention to supporting their workers in terms of facilitating infrastructure and creating a conducive environment. The IT industry in Pakistan has experienced tremendous growth since the late 1990's whence over $\$ 2$ billion growth has been recorded by the industry (IITEC Pakistan, 2012). Governments in the last decade have also lent support to the industry in the form of tax exemptions, establishment of IT parks (network of IT offices working under one roof), and by encouraging foreign firms to invest either through outsourcing or through complete ownership. In context of the global world economy, the economy of Pakistan as being a developing one is placing emphasis on achieving economies of scale that will create a ripple effect on other sectors. The establishment of the IT industry has caused business processes to improve considerably despite the prevailing energy crises in the country.

In spite of the growth of Pakistan's nascent IT industry, the emphasis is still on execution and actual delivery, while many aspects and practices of project management leading up to the implementation go unexplored, creating technical problems later (Haider, 2004). Therefore, project management severely demands the attention of project managers to enhance productivity. As many new technologies have been acquired from foreign vendors, better utilization of those technologies is the primary concern of project managers. Such 
technologies typically comprise database management systems, IT solutions for information security, office and banking automation, networking, e-commerce, specialized online testing services, and telemedicine. All these fields need careful analysis and handling for relevant projects to be successfully completed. In addition, the success of a project is measured best through how it responds to the primary constraints of Scope, Cost, and Time and how projects correspond with the success criteria of project management (Schwalbe, 2007). Progression on a project is also highly dependent upon human capital and expertise employed. Besides employing the skill factor, it is also necessary to maximize human potential through a conducive and supportive contextual work environment, as the human resource of a project should be viewed in totality as a synergism of its motivation, behavior, and creativity. When investigating the effects of the work environment, the present study has taken into account the triple constraints of project management as benchmarks of success. Because of high uncertainty and complexity of projects, it is imperative for managers to independently handle all components of triple constraints, notwithstanding there exists human expertise (Shenhar et al, 2002). This study postulates that factors associated with the work environment may be affecting the ability of a project team, which in turn affects the triple constraints of a project.

\section{Literature Review}

Work Environment in Project Management: The most prevalent rationale for a work environment to exist is the projects ongoing in an organization, which bring together people, processes, technologies and the physical environment. Work environment is reflected in the way employees' performances are appraised, workers become productive through teamwork (Gummer, 2001) and people see their career progression with a view of innovation and dynamism. Although there are a number of factors prevailing within and outside the organization, which form its work environment, primarily the organizational design, structure, and functions related to production, marketing, and human resources refer to a physical work environment. Some secondary components also come into play, such as employees' perceptions of work, which are part of the intangible work environment as implied by the Work Environment Scale (Insel \& Moos, 1975). In the organizational context, work environment refers to a broader view of an organization consisting of features such as technology and facilities, job skills, co-workers, work quality, remuneration, job satisfaction, management, employee welfare packages, and work related benefits and incentives. There are no specific criteria for measuring work environment as being good or bad from the standpoint of management and employees. Organizations use multiple strategies to deal with how working environment can correspond to project management. Foremost of those measurement approaches is to measure an individual's performance and growth initiative, handling of certain projects, working extra hours, goal attainment, and perception of job security. A combination of the stated factors can be decisive in measuring projects' success (Wright et al, 2001). To build upon Wright's argument, the present study uses an intangible construct of the work environment consisting of Remuneration, Job Satisfaction, Job Security and Working Hours to determine project managers' perception of the work environment. Considering remuneration as part of work environment proves to be healthy for organizations, as project managers view it a motivating factor.

The performance-based pay criteria has been quite result-oriented, positively affecting project triple constraints, but must be viewed along with job satisfaction and job security, which are all actors in the work environment (Woolfolk \& Davis, 2006). Project managers feel content in the environment where projects are viable and rewarding. Due to the extremely sensitive nature of projects, particularly related to information technology, project managers view a suitable environment as imperative for them to be satisfied (Oshagbemi, 2000). Thus, healthy work environment and thriving efficiency in relation with optimized triple constraints is desirable (Akinyele, 2007). Very compelling evidence in support of organizational work environment are those despondent and unsatisfied employees who prove to be an implicit liability for their organizations. Employees' job satisfaction has always been the core issue for organizations through which project management goals are achieved. To maintain a healthy environment, organizations tend to keep their employees content and happy by providing them with sound contextual environment (James \& Jones, 2004). As a result, projects become productive and rewarding because satisfied project manager's start delivering by matching their skills with the tasks (Reichers, 2006). Work environment has no specific definition; rather it is observed in different dimensions. Opperman (2002) has aptly partitioned environment of work into three different areas: 1) Technical, 2) Human, and 3) Organizational. Unless these areas of work environment are explored and developed, organizations cannot practice and enjoy the real values and philosophy of work 
environment. These values create a sense of ownership in project managers. As a result, managers form a profound sense of affiliation with their work environment, which affects their skills and approaches positively. Comparing organizations as being static or dynamic, the people who are part of static organizations are less productive and creative, whereas people working in dynamic organizations are more creative and have a lucid approach (Scotter, 2000).

Triple Constraints: Apart from making a project novel, technologically sound and commercially profitable, triple constraints need to be effectively employed to define realistic goals towards which the entire resources of the project are directed. Completing projects on time while minimizing costs is imperative for projects, but these should not jeopardize overall scope. According to the project management perspective, it is the responsibility of project managers to first explore technical aspects of projects in relation to scope and limitations, and then cost and time factors (Taylor, 2004). Project managers regard triple constraints as key to a project's requirements and success. Optimizing these three features ascertain project quality and timely completion. All three constraints of projects - scope (a measure of quality), cost and time - have their respective effects on projects' performance but since these elements have some correlation, any one constraint bears an effect on the other two, eventually affecting projects deliverables to a greater extent (Brewer \& Dittman, 2010). For instance, in terms of scope, sometimes projects are operationally modified; undoubtedly, period and cost of projects are also likely to change. Therefore, altogether, triple constraints have substantial effects on projects deliverables and results. Similarly, expanding or contracting the time of projects would surely change the cost structure of a project. Any change in the cost structure would compel managers to increase or decrease the period of projects. Keeping to initially defined project scope, cost or time would not be possible in practice since there are always fallback plans by the management, which force project teams to reshuffle the resources, evidently affecting project results. Rubenstein (2007) had cues from a study conducted in 2006 that most projects do overrun time and cost constraints and are unable to meet projects' expectations. The responsibility of making triple constraints effective and result oriented also lies on the management and depends on how well an orientation it gives to employees about the project. Since employees need differing orientations befitting their respective roles, skills and capabilities, training them in this regard is highly advisable. Usually the project team is given on-the-job training, adapting them to projects needs and requirements (Holton et al, 2000). In order to make triple constraints effective, a controlled work environment will also play a key role towards strong project management. An ideal work environment favorable in employees' interests will proceed to trigger the motivational level of employees. A motivated project manager is likely to deliver maximum results stemming from his clear vision, better utilization of resources, and scheduling of respective tasks with ease and freedom, thus ensuring sound and effective triple constraints in the interest of project management. Hartman (2000) is of the view that a project's success cannot be ensured only through triple constraints; rather project managers need to wait and see the completion phase of projects, which indicate how much of return has been earned against the net investment. Project success does not only refer to the achievement of project objectives with well-managed triple constraints, but could also be indicated through partial achievements by managers such as skill development or certain innovation during experimentation (Cleland \& Ireland, 2007). Being such a key indicator of project success, it is the triple constraint (scope, time, and cost) which is to be synthesized with the contextual work environment (Ingram, 2000).

\section{Research Objectives}

- To identify a relationship between work environment and triple constraints

- To assess how effective selected constructs in the work environment are as determinants of triple constraints in project management.

Research Hypothesis: To investigate the relationship between work environment and the triple constraint of project management, the following hypotheses were developed:

$\mathbf{H}_{\mathbf{0}}$ The work environment of a project has no influence on its triple constraint.

$\mathbf{H}_{\mathbf{1}}$ There exists a relationship between project's work environment and the triple constraint. 


\begin{tabular}{|l|l|}
\hline Figure 1: Conceptual Framework & \multicolumn{1}{|c|}{ Project Management } \\
Work Environment & Triple Constraint \\
Non-Physical Constructs & Scope \\
Remuneration & Time \\
Job Satisfaction & Cost \\
\cline { 2 - 2 } Job Security & \\
Working Hours & \\
\hline
\end{tabular}

\section{Methodology}

Sample: Convenience sampling allowed for three hundred project managers of different IT companies and software houses across two cities to be approached for the study. Two hundred seventy nine managers aged 25 to 65 years responded. Male respondents were 235; making 84 percent of the total sample size, while female counterparts were 44 with a percentage of about 16 percent. From the educational perspective, 12\% of the respondents were undergraduates, followed by $80 \%$ respondents with degrees and only $8 \%$ were Masters' or MS.

Instrument and Procedure: The empirical survey partially adopted the questionnaire for one of the constructs, Job Satisfaction, already used by Caprara, Barbaranelli, and Malone (2006); for all the other constructs of the study, i.e. Remuneration, Job Security, Working Hours, Scope, Time and Cost. The researcher developed the tool and tested it on one hundred respondents in a preliminary pilot study. The pilot study revealed the reliability of multiple items of the tool (Spector, 1992) having Cronbach Alpha values of 0.80, $0.65,0.62,0.70,082,0.76$, and 0.85 for Remuneration, Job Satisfaction, Job Security, Working Hours, Scope, Time and Cost respectively. For each item the questionnaire followed a five-point Likert scale ranging from 'strongly disagree' to 'strongly agree'. For data analysis, SPSS was used to apply Independent Sample $t$-test, ANOVA, Correlation Analysis, and Regression Analysis.

\section{Results}

The study presumed that project managers could effectively manage the triple constraint regardless of the work environment. The results of the study do not coincide with the presumption. Therefore, the Null Hypothesis is rejected, maintaining that work environment does indeed affect the triple constraint of a project. The results are explained as under:

Correlation Matrix of Variables: In Table 1, Correlation has been used to study the degree of association between the stated variables and by summarizing the values of Pearson's correlation coefficient. The results indicate that at $5 \%$ level of significance, Triple Constraint is positively correlated with Remuneration, Job Satisfaction, Job Security, and Working Hours as the value of the correlation coefficient were 0.398, 0.387, 0.206 , and 0.377 respectively. The results of the study prove that the model is significant and that the triple constraint of project management is positively correlated with the work environment of projects.

Table 1: Correlation Matrix of Variables

\begin{tabular}{|c|c|c|c|c|c|}
\hline \multicolumn{2}{|c|}{ No of Res: 279 Correlations } & $\mathbf{R M}$ & JS & $\begin{array}{l}\text { JSC } \\
\text { (Min1, } \operatorname{Max} 5)\end{array}$ & Triple Con \\
\hline \multicolumn{6}{|c|}{ Work Environment } \\
\hline Remuneration & $\begin{array}{l}\text { Pearson Correlation } \\
\text { Sig. (2-tailed) }\end{array}$ & 1 & & & \\
\hline \multirow[t]{2}{*}{ Job Sat } & Pearson Correlation & 0.523 & 1 & & \\
\hline & Sig. (2-tailed) & 0.000 & & & \\
\hline \multirow[t]{2}{*}{ Job Sec } & Pearson Correlation & 0.769 & 0.819 & 1 & \\
\hline & Sig. (2-tailed) & 0.000 & 0.000 & & \\
\hline \multicolumn{2}{|c|}{ Working Hrs Pearson Correlation } & 0.922 & 0.566 & 0.838 & \\
\hline
\end{tabular}




\begin{tabular}{cccccc}
\hline Sig. (2-tailed) & 0.000 & 0.000 & 0.000 & & \\
Triple Constraints & & & & & \\
Pearson Correlation & 0.398 & 0.387 & 0.206 & 0.377 & 1 \\
Sig. (2-tailed) & 0.000 & 0.000 & 0.000 & 0.000 & \\
\hline
\end{tabular}

Correlation is significant at the 0.01 level (2-tailed).

Table 2: Regression Analysis

\begin{tabular}{llccc}
\hline Model & R & R Square & Adjusted R Square & Etd. Error of the Est \\
\hline 1 & 0.969 & 0.937 & 0.929 & 0.8963 \\
a. Predictors: (Constant), Work Environment & & \\
b. Dependent Variable: Triple Constraint & & \\
\hline
\end{tabular}

The result of regression for work environment and triple constraint is presented in Table 2 . The $\mathrm{R}$ square value estimates how well the model fits the sample. Goodness of fit is reflected through Adjusted R square. The R square is 0.937 , which indicates that 93.7 percent of the variation in triple constraint can be explained by variability in the work environment of projects. Furthermore, it is indicative of work environment's impact on the triple constraint. According to the analysis, Work Environment is a strong predictor of Triple Constraint. Therefore, the model proves to be significant.

Table 3: Group-wise Analysis of Scope, Time, and Cost between Male and Female Employees

\begin{tabular}{lllll}
\hline & Group & Mean & Std Dev & P-Value \\
\hline Time & Male & 4.024 & .3735 & .168 \\
& Female & 3.879 & .2972 & \\
Cost & Male & 3.932 & .1347 & .993 \\
& Female & 3.932 & .1360 & \\
Scope & Male & 3.698 & .2450 & .752 \\
& Female & 3.705 & .2487 & \\
\hline
\end{tabular}

Source: Field Data

Independent Sample $\boldsymbol{t}$-test: Independent Sample $t$-test is presented in Table 3, which analyzes the mean scores of two groups i.e. male, and female, which is measured at the 0.05 significance level. Since $P>\alpha$, the result of the $t$-test indicates that there is no significant difference between the two groups with respect to Scope, Time and Cost (Triple Constraint).

Table 4: Analysis of variance of Time, Cost, and Scope with respect to demographics i.e. Age and Education

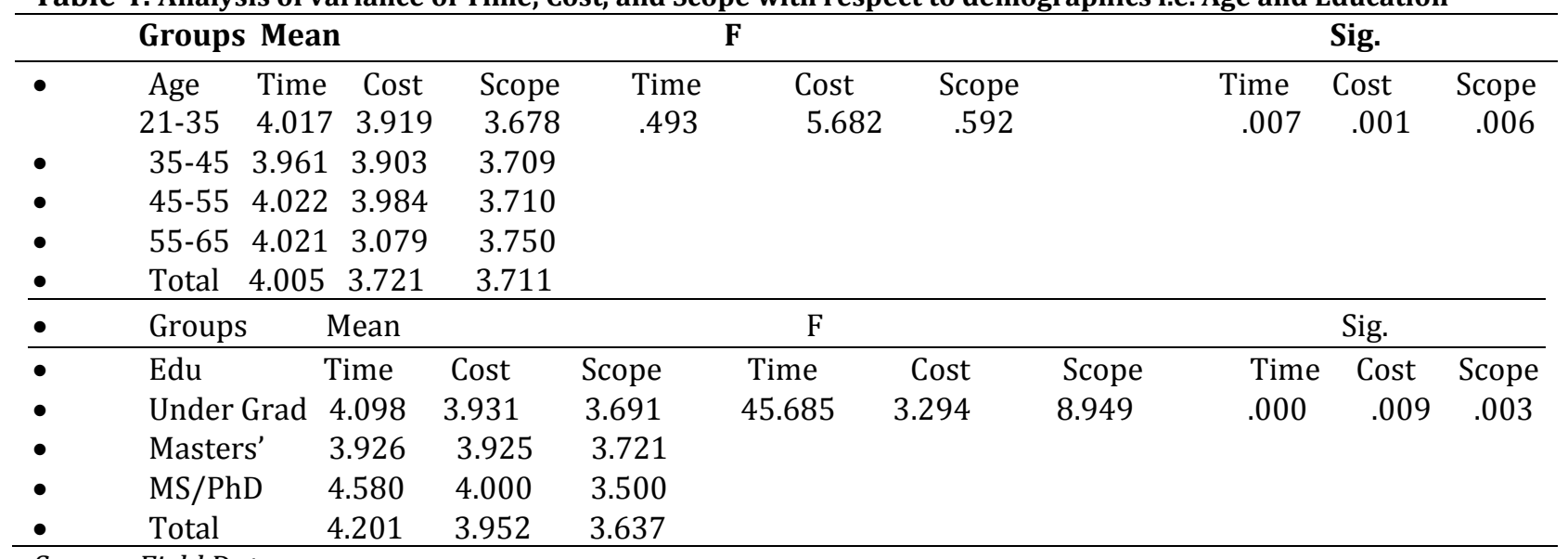

Source: Field Data

Analysis of Variance (ANOVA): One - way ANOVA is presented in Table 4, which assesses whether there is some statistical mean difference in response to two demographic characteristics i.e. age and education. 
According to the table, there is no significant difference in the response with respect to age and education as $\mathrm{p}$ $<0.05$. The mean with respect to age and education is 4 on average, indicating that managers belonging to different age brackets and having diverse educational backgrounds are of the same opinion about triple constraint factors of a project. They suggest a strong relationship and positive correlation between work environment and triple constraint of IT projects. The F value in the given case is also greater than the critical value of $\mathrm{F}$, meaning thereby that the proposed hypothesis $\mathrm{H}_{1}$ is to be accepted. Therefore, the results indicate that the model is significant.

Discussion: The findings of the study indicate that there is a significant relationship between the components of work environment and the triple constraint of project management and both the independent and dependant variables are positively correlated. This finding is somewhat consistent with the finding of Turner and Muller (2006), a similar study where responses of project managers were analyzed, and they concluded that a high degree of project complexity increased the effectiveness of the triple constraint. In another study, project managers working in a conducive environment and running projects independently could effectively manipulate the triple constraint, and a flexible work environment led to positive job performance, as demonstrated by Nkom (2000). Ajayi (2011) studied work environment as correlate of staff job performance in south west Nigerian universities and concluded that work environment of the universities was a determinant of the academic staff job performance thus positively affecting projects of the organization. A study from Durotolu (2000) concluded no significant relationship between the work environment and employees performance ultimately resulting in triple constraints. This contradicts the present study's inference regarding the hypothesis, which was tested that there exists a relationship between a project's work environment and the triple constraint of project management. Whereas previous studies have laid emphasis on managers' work practices and attitudes towards work, the present undertaking has essentially explored the effects of the non-physical work environment on the triple constraint faced by project managers. Some analysts have also commented on building the employees' motivational level for better productivity. This stance pleaded for the behavioral stimulation of project management in addition to promoting physical infrastructure (Schneider, 2008). The triple constraint criterion is a typical one to evaluate projects' success since it is used primarily to assess the financial worth of projects. However, other than this traditional approach, the entire work system needs to be enhanced with additional components, which are considered direct inputs for a sound completion of projects, since triple constraints employed alone cannot ensure project success. Kpangban and Onwuegbu (1995), Ariyo (2000), and Aiyegbusi (2000) strongly favored a better work environment as a determinant of managing triple constraint. A healthy work environment is positively associated with the output and productivity of projects and triple constraints of projects are likely to be extremely effective in the presence of that healthy work environment (Oni, 2000). Additional inputs of work environment, such as relevant adeptness of project managers, reliability of projects and maintenance services, should also be considered simultaneously in the conventional framework of triple constraints so as to make projects more viable and capable of giving returns (Han \& Huang, 2007). Combining all the components of the work environment could possibly lead to a successful project having well managed triple constraint.

\section{Conclusion}

The study concludes that project managers view work environment as an important determinant of the triple constraint. Remuneration packages being paid to project managers are an inevitable boost to the productivity of projects. Project managers who are more satisfied are better performers of IT project management. Greater job security is another factor, which leads to better, managed triple constraint of projects, probably because it enables the project team to be more focused. Non-physical work environment - consisting of remuneration, job security, job satisfaction elements and flexible working conditions - boosts the managers' morale and directly affects the productivity of projects. The present study implies a very strong relationship between these components of work environment and project performance, which is measured in the form of well-managed triple constraints. Based on the findings of the research, the proposed model is significant and hypothetically accepted.

Limitations: The model only considers limited components of the work environment as determinant of triple constraints, whereas a number of other components physical in nature can also considered to examine their 
effects. Besides, the research mainly focuses on IT project management and can take into consideration other sectors of the economy since reliance cannot be placed on a single industry for eliciting such an imperative inquiry into primary constraints of project management. Another remarkable limitation of the existing research is that presently, triple constraints are not considered the only milestone in project management, since many additional inputs have been added into the primary constraint model.

Recommendations: The role of work returns and incentives cannot be overlooked in project management. Project managers should be acquainted with the academic and practical aspects of Project Management where all technicalities regarding management of triple constraints should be communicated to them. Training programs for project teams are significant, along with behavioral nourishment of employees. In order to effectively manage projects, a broader perspective of triple constraints is required.

\section{References}

Aiyegbusi, J. T. (2000). Communication of effective classroom instruction. Journal of Business and General Studies, 1(1), 31-35.

Ajayi, I. A. (2011). Work environment as correlate of academic staff job performance in southwest Nigerian universities. European Journal of Educational Studies, 3(1).

Akinyele, S. T. (2007). A Critical Assessment of Environmental Impact on Workers Productivity in Nigeria. Res. J. Bus. Manage., 1(1), 50-61.

Ariyo, S. K. (2000). A socio-linguistic study of the English medium of instruction in Nigerian educational system. Journal of Business and General Studies, 1(1), 105-112.

Brewer, J. \& Dittman, K. (2010). Methods of IT Project Management, (1 ${ }^{\text {st }}$ Ed.), Upper Saddle River, NJ.

Caprara, G. V., Barbaranelli, C., Steca, P. \& Malone, P. S. (2006). Teachers' self-efficacy beliefs as determinants of job satisfaction and students' academic achievement: A study at the school level. Journal of School Psychology, 44(6), 473-490.

Cleland, D. I. \& Ireland, L. R. (2007). Project Management: Strategic Design and Implementation, (5 $5^{\text {th }}$ ed.) McGraw-Hill, New York.

Cooke-Davies, T. (2002). The real success factors on projects. International Journal of Project Management, 20, 185-190.

Durotolu, A. O. (2000). Administrative environment as a factor of academic staff performance in College of Education in Kwara State, Nigeria. Unpublished Ph.D. thesis, University of Ibadan, Ibadan, Nigeria.

Gummer, B. (2001). Peer relationships in organizations: Mutual assistance, employees with disabilities, and distributive justice. Administration in Social Work, 25, 85-103.

Haider, A. (2004). Software Productivity: The impact of Soft Factors, Proceedings of International Conference on Software Engineering and Applications, Organized by IEEE \& Foundation University, December 31, 2004, Islamabad, Pakistan.

Han, W. M. \& Huang, S. J. (2007). An empirical analysis of risk components and performance on software projects. The Journal of systems and software, 80, 42-50.

Hartman, F. T. (2000). Don't Park Your Brain Outside. Newtown Square, PA: Project Management Institute.

Hartenian, L., Schellenger, M. \& Frederickson, P. (2001). Creation and assessment of an integrated business course: One college's experience. J. Educ. Bus., 76(3), 149-159.

Holton, E. F., Bates, R. A. \& Rouna, E. A. (2000). Development of a generalized learning transfer system inventory. Human Resource Development Quarterly, 11(4), 333-360.

IITEC Pakistan. (2012). Retrieved from http://www.iitec.com.pk/Downloads/IITEC\%20Presentation.pdf

Ingram, G. (2000). The way to enlightened project management, Project Manager Today

Insel, P. M. \& Moos, R. H. (1975). Work Environment Scale. Palo Alto, CA: Consulting Psychologists Press.

James, O. J. \& James, O. P. (2004). The Meaning of Organizations: The Role of Cognition and Values. Organizational Climate and Culture, 5(2), 40-84.

Kpangban, E. \& Onwuegbu, O. C. (1995). Principles and methods of teaching: a practical guide to effective teaching (2nd ed.). Agbor: Pon Publishers Limited.

Nkom, A. A. (2000). Instructional communication for effective teaching in university education. Kaduna: B1 Shaanu Publishing.

Oni, J. O. (2000). Downward pressure on staff salaries and deteriorating working conditions on campus. A Status Report; Division of Business and Finance, University of Nemphilis. 
Opperman, C. S. (2002). Tropical Business Issues. Partner Price Water House Coopers.

Oshagbemi, T. (2000). Gender Differences in the Job Satisfaction of University Teachers. Women in Management Review, 15, 331-343.

Project Management Institute (PMI). (2004). Four Campus Boulevard, Newton Square, PA 19073-3299 USA, (www.pmi.org).

Project Management Institute. (2004). A guide to the project management body of knowledge (PMBOK®) (Third ed.). Newtown Square, PA: Project Management Institute.

Reichers, A. E. (2006). A Review and Reconceptualisation of Organizational Commitment. Academy of Management Review, 10(3), 465-476.

Rubenstein, D. (2007). Standish Group Report: There is Less Development Chaos Today. Software Development Times on the Web.

Schneider, I. I. (2008). Motivation and Organizational Climate. Journal of Personnel Psychology, 29(3), 371392.

Schwalbe, K. (2007). Information Technology Management, (5 ${ }^{\text {th }}$ ed.) Thomson.

Scotter, J. R. V. (2000). Relationships of Task Performance and Contextual Performance With Turnover, Job Satisfaction, and Affective Commitment. Human Resource Management Review, 10(I), 76-95.

Shenhar, T. A., Dvir, D., Lipovetsky, S. \& Lechler, T. (2002). Refining the search for project success factors: a multivariate, typological approach. $R \& D$ Management, 32(2), 111-26.

Spector, P. (1992). Summated rating scale construction. Thousand Oaks, CA: Sage.

Warmbrod, J. R. (2001). Conducting, interpreting, and reporting quantitative research. Research Pre-Session, New Orleans, Louisiana.

Taylor, M. D. (2004). A Guide to the Project Management Body of Knowledge, Third Edition (Project Management Institute: Newton Square, PA.

Turner, J. R. \& Muller, R. (2006). Choosing Appropriate Project Managers: Matching their leadership style to the type of project. Project Management Institute, Newton Square, PA, USA.

Woolfolk, H. A. \& Davis, H. A. (2006). Teacher self-efficacy and its influence on the achievement of adolescents. In F. Pajares \& T. Urdan (Eds.), Self-efficacy of adolescents (117- 137). Greenwich, Connecticut: Information Age Publishing.

Wright, P. M., Garner, T. M., Moynihan, L. M., Gerhart, B., Delery, J. E. (2001). Measurement error in research on human resources and firm performance: additional data and suggestions for further research Personnel Psychology, 54, 875-901. 